\title{
THE EFFECT OF DISCOVERY LEARNING MODEL AND SOCIAL SKILLS ON STUDENT LEARNING OUTCOMES PPKN SUBJECTS IN CLASS V SDN 034799 DOLOKTOLONG
}

\author{
Paska Sriulina Tarigan ${ }^{1}$ \\ State University of Medan, Indonesia \\ E-mail : Paskasritarigan96@gmail.com \\ Deny Setiawan'2 \\ State University of Medan, Indonesia \\ Sri Milfayetty ${ }^{3}$ \\ State University of Medan, Indonesia
}

\begin{abstract}
This study aims to determine: 1) The influence of discovery learning and expository learning models on student learning outcomes, 2) The influence of social skills on student learning outcomes. 3) The interaction between learning models and social skills on student learning outcomes. This study used a quasiexperimental research method. The research was conducted from April to May 2021.The population of this study were 48 students of grade V SDN 034799 Doloktolong who were chosen randomly by random sampling technique. The sample is the VA class as many as 24 people as the experimental class and the VB class as many as 24 people as the control class. Data collection techniques using social skills questionnaires and learning outcomes tests. The data analysis technique used two-way analysis of variance. The results of the study are as follows: (1) There are differences in learning outcomes students who were taught with the discovery learning model with an average value of 85,556 higher than the learning outcomes of students taught by the expository learning model with an average of 76,944, the results of the analysis of variance showed that the $F_{\text {count }}$ value was $71.11>$ the $F_{\text {table }}$ value was 3.20 and the probability or significance value $0.00<0.05$, so $\mathrm{HO}$ is rejected; (2) There is a significant difference between the learning outcomes of students with high social skills and the average84,364and students who have low social skills on average 67.00. Result
\end{abstract}


of analysis of variance obtained $F_{\text {count }}$ value of $17.35>F_{\text {table }}$ value of 3.20 and $a$ significant value of $0.017<0.05$, so that $\mathrm{HO}$ is rejected; (3) There is an interaction between discovery learning models and students social skills in improving student PPKn learning outcomes, the results of analysis of variance $F_{\text {count }}$ value of 6,021> $F_{\text {table }}$ value of 3.20 and a significance of $0.018<0.05$, so that $\mathrm{HO}$ is rejected.

Keywords: learning models, social skills, PPKn learning outcomes

\section{A. Introduction}

This pandemic has an impact on various fields, one of which is in education. Many countries have decided to temporarily close schools and campuses during the COVID-19 pandemic. Each country makes policies to overcome the problems that are happening. To overcome the Covid-19 pandemic, all countries implemented an action, one of which was by carrying out social distancing movements, namely social distancing designed to reduce the interaction of people in the wider community (Wilder-Smith \& Freedman, 2020: 2).

One problem What is being faced by the world of education in Indonesia apart from the COVID-19 pandemic, especially at SDN 034799, is the weakness of the learning process and students social skills. In the learning process, students are less encouraged to develop thinking skills and social skills. The learning process in the classroom is directed at the ability of students to memorize a number of information, the student's brain is forced to remember and hoard various information, without being required to understand the information it remembers to relate it to everyday life. As a result, when students graduate from school, they are theoretically smart but poor in applications including with their social skills. 
To overcome the problems above, one of the learning models that will be applied to class V SD Negeri 034799 Doloktolong is a discovery learning model by applying its aspects starting from the stimulation stage (stmiulation), statement/problem identification (problem statement), data collection (data collection), data processing (data processing), verification (verification), drawing conclusions/generalizations (generalization). At the initial stage, students are given the stimulus to think about the initial problem about the material to be studied. At this stage, students cognitive development focuses more on thinking skills.

The selection of the right model can create a pleasant learning situation and support the smooth teaching and learning process so that students will be more motivated to learn. The selection of the model needs to pay attention to several things, such as the material presented, its objectives, the time available, the number of students and matters relating to the teaching and learning process. A good teacher must be able to master various teaching models so that they can choose and determine the right model to be applied to certain learning materials. The learning model is a pattern used by teachers in delivering teaching materials.

Based on initial observations made on fifth grade students of SD Negeri 034799 Doloktolong, it is known that the learning outcomes of Civics and social skills are still low. This can be seen from the percentage of monthly test scores for Civics subjects for class $V$ students.

To overcome this problem, a teacher in delivering material needs to choose a model that is suitable for students and class conditions so that students are interested in participating in the learning process. In addition, the application of innovative and varied models in classroom learning can make students actively participate in the learning process so 
that student learning outcomes can increase.

\section{B. Method}

\section{Research sites}

This research was conducted at the State Elementary School 034799 Doloktolong Kec. Sumbul Kab. Dairi with the consideration that (1) this elementary school has never applied the discovery learning model, (2) the number of students who are suitable to be used as research samples, (3) this elementary school is an accredited school.

\section{Population and Research Sample}

The population of this research is all students of class V SD Negeri 034799 Doloktolong FY 2020/2021 totaling 48 people, students are divided into 2 classes, namely class VA totaling 24 people and class VB totaling 24 people. Researchers take samples using random sampling techniques.

\section{Research procedure}

The implementation of the treatment in this study was adjusted to the learning activities that took place at SD N 034799 Doloktolong for class $\mathrm{V}$ students. The materials and subject matter were prepared referring to the expository learning model and the discovery learning model for the socio-cultural diversity of Indonesian society in class V SD. The steps in this research are as follows:

1. Initial stage (Preparation and Planning)

2. Reporting stage, compiling data analysis and conclusions of research results in the form of a final report/thesis.

\section{Data collection technique}

1. Tests for the cognitive domain, which are used to determine student learning outcomes using multiple choice tests. In this case, student 
learning outcomes are only viewed from the cognitive domain based on Bloom's Taxonomy. The data needed in this study is data on student learning outcomes from posttest assessment. Posttest is the final test of the experiment or the final test, which is a test carried out after the experiment. The purpose of this posttest is to obtain evidence of the effect of discovery learning on student outcomes for the experimental class.

2. Observation is used to observe student learning outcomes by using discovery learning.

3. Questionnaires are used to determine students learning social skills.

\section{Data analysis technique}

Data analysis techniques in this study are descriptive and inferential techniques. Descriptive technique is used to describe research data such as arithmetic mean, standard deviation, median, mode, frequency distribution. While the inferential technique used to test the research hypothesis is a two-way analysis of variance (ANAVA) technique. In this case the use of analysis of variance, after testing the requirements first, namely the normality test using the Lilieofors test (Lo $<\mathrm{Lt}$ ) at a significant level of $5 \%$ with the provision that if it turns out Lo $<\mathrm{Lt}$ then the data tested is normally distributed. Furthermore, the homogeneity of variance test was carried out using the Fisher $(F)$ test and continued by using the Barlett test $\chi^{2 \mathrm{~h}}<\chi^{2 \mathrm{t}}$ then the data is declared homogeneous.

\section{Finding and Discussion}

\section{Results}

Based on the analysis design, the distribution of power frequencies presented are: (1) pre-test of civics learning outcomes of experimental class students, (2) pretest of civics learning outcomes of 
control class students, (3) description of social skills of experimental class students, (4) description of social skills of control class students, (5) post test of Civics learning outcomes of students who are taught by discovery learning learning model, (6) post test of Civics learning outcomes of students who are taught by expository learning model, (7) Civics learning outcomes of students who have social skills high, (8) Civics learning outcomes of students who have low social skills, (9) Civics learning outcomes of students who are taught by discovery learning models and have high social skills, (10) Civics learning outcomes of students who are taught by discovery learning model learning and have low social skills, (11) Civics learning outcomes of students who are taught by expository learning model and have high social skills and (12) Civics learning outcomes of students who are taught by expository learning model and have low social skills

1. Pre-Test of Experimental Class Civics Learning Outcomes

PPKn learning outcomes of students in the experimental class with the highest number of frequencies were in the interval class 67-74, namely 8 people or $33 \%$ of students, while the least number of frequencies was in the interval class $43-50$, namely 2 people or $7 \%$ of students.

2. Pre Test of Civics Learning Outcomes for Control Class Students

Civics learning outcomes of students in the control class with the highest number of frequencies are in the interval class 47-53, namely 9 people or $38 \%$ of students, while the least frequency is in the interval class 33-39, namely 1 person or $4 \%$ of students.

3. Description of Experimental Class Student Social Skills

24 students in the experimental class there were 10 students or $41 \%$ of students who had high social skills, 14 people or $59 \%$ of students [548] 
who had low social skills. The frequency distribution of students social skills scores is visually shown in the following diagram.

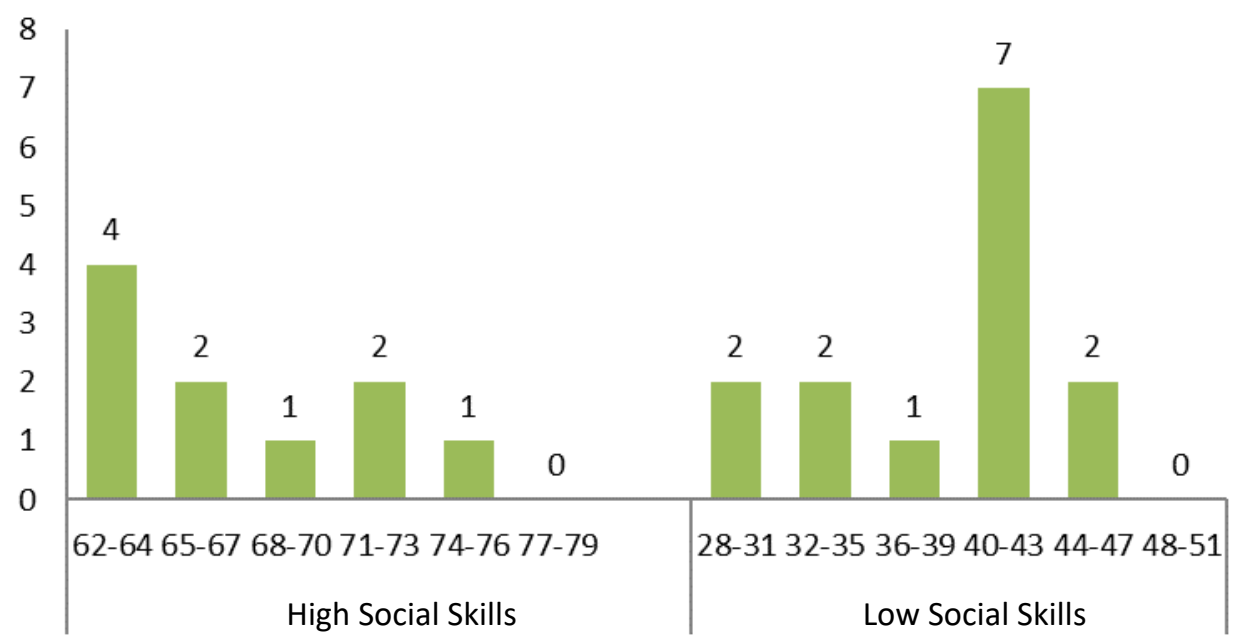

Figure 1. Experimental Class Social Skills Diagram

4. Description of Control Class Social Skills

24 students in the control class, there are 8 students or $33 \%$ of students who have high social skills and 16 students or $67 \%$ of students have low social skills. The frequency distribution of scores for having students social skills is visually shown in the following diagram.

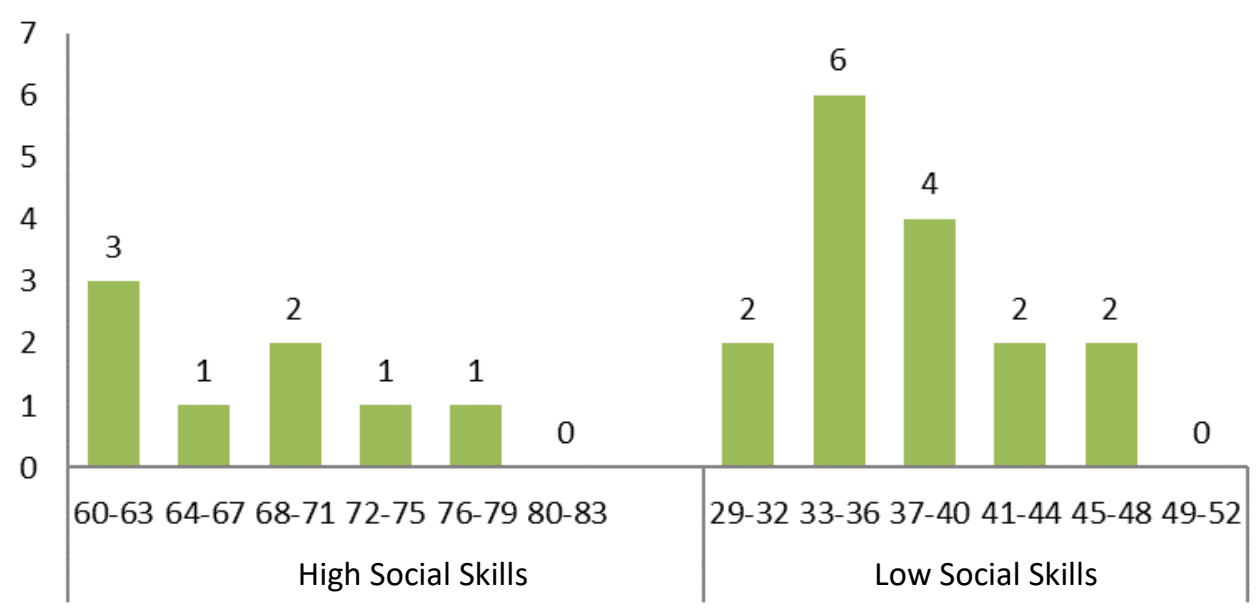


Figure 2. Social Skills Diagram Control Class Students

5. Post Test of Civics Learning Outcomes of Students Taught with the Discovery Learning Model

From the data obtained and the results of statistical calculations, it is known that the Civics learning outcomes of students who are taught with the discovery learning model get the lowest score of 67 and the highest score of 100 with an average of 85.55, the largest variance of 88 and a standard deviation of 9.00 .

Civics learning outcomes of students who are taught with the discovery learning model the highest frequency is in the interval class 8590 , namely 8 people or $33 \%$ of students, while the lowest frequency is in the interval class $97-102$, namely 2 people or $8 \%$ of students, and $67-72$ that is 2 people or $8 \%$ of students.

6. Post Test of Civics Learning Outcomes of Students Taught with Expository Learning Model

Civics learning outcomes of students who are taught using the expository learning model are in the interval class 79-84, namely 7 people or $29 \%$ of students, while the lowest frequency is in the interval class $97-$ 102 , namely 1 person or $4 \%$ of students.

7. Civics Learning Outcomes of Students with High Social Skills

Civics learning outcomes of students who have high Social Skills with the highest number of frequencies are in the interval class 66-68, namely 5 people or $29 \%$ of students, while the lowest frequency is in the interval class 69-71, namely 1 person or $6 \%$ of students.

8. Civics Learning Outcomes of Students Who Have Low Social Skills

Civics learning outcomes of students who have low social skills with the highest number of frequencies are in the 43-46 interval class, namely 8 people or $26 \%$ of students, while the lowest number of [550] 
frequencies is in the $27-30$ interval class, namely 2 people or $6 \%$ of students.

9. Civics Learning Outcomes of Students who are Taught with the Discovery Learning Model and Have High Social Skills

Civics learning outcomes of students who are taught with discovery learning models and have high social skills with the highest number of frequencies are in the interval class $86-87$, namely 4 people or $27 \%$ of students, while the least frequency is in the interval class $82-83$, namely 0 people or $0 \%$ of students.

10. Civics Learning Outcomes of Students who are Taught with the Discovery Learning Model and Have Low Social Skills

Civics learning outcomes of students who are taught with discovery learning models and have low social skills with the highest number of frequencies are in the 53-54 interval class, namely 8 people or $44 \%$ of students, while the least frequency is in the 55-56 interval class, which is 0 people or $0 \%$ of students.

11. Civics Learning Outcomes of Students who are Taught with Expository Learning Models and Have High Social Skills

Civics learning outcomes of students who are taught with expository learning models and have high social skills with the highest number of frequencies are in the interval class 64-66, namely 4 people or $44 \%$ of students, while the lowest frequency is in the interval class 67-69 and 73-73 .

12. Civics Learning Outcomes of Students who are Taught with Expository

Learning Models and Have Low Social Skills

Civics learning outcomes of students who are taught with expository learning models and have low social skills with the highest number of frequencies are in class $48-50$, namely 3 people or $33 \%$ of 
students, while the lowest frequency is in the interval class 51-53, namely 1 person or $11 \%$ of students.

\section{Discussion}

Civics Learning Outcomes of Students Taught with the Discovery Learning Model are Higher than Students Taught with the Expository Learning Model

Quality education will be able to produce quality resources, have expertise, appear, be creative, productive, have positive behavior and always love the culture of the homeland and nation. Quality education will be able to help students in the self-development process, namely the development of all their potential, abilities, skills and personality characteristics towards positive character values that will strengthen the identity and national identity they already have (Suswandari, 2015).

Based on the results of the research conducted, it was found that the average Civics learning outcomes of students taught with discovery learning learning models was 85.55, meanwhile, the average Civics learning outcomes taught by expository learning was 76.94, therefore it can be said that Civics subjects, especially in studying the socio-cultural diversity of Indonesian society, considering the average learning outcomes obtained by students using the discovery learning model is higher than the average student learning outcomes taught by the expository learning model that has been used by teachers in Civics subjects. .

Based on the results of the analysis during the research process, the researcher observed that each student had different abilities in understanding the lesson. The continuity of this research makes researchers closer to the problem. The core of the problem found is that [552] 
Civics learning outcomes are not achieved, students need to be close to the socio-cultural diversity of the community. Therefore, by applying discovery learning learning can help students easily understand the concepts and socio-cultural diversity of the community. Based on this thought, it can be said that student Civics learning outcomes will be better and increase if teachers apply discovery learning learning models in helping the daily learning process.

\section{Civics Learning Outcomes of Students with High Social Skills are Higher than Students with Low Social Skills.}

Students who have high social skills will have more skills to control themselves, motivate themselves, have enthusiasm, communicate well, be diligent and have the skills to interact with fellow students or teachers in the learning process compared to students who have low social skills. Therefore, students who have high social skills will gain knowledge that is more meaningful and stored well in students memory so that it will be easy for students to answer all questions, hence, student learning outcomes of Civics will also be high.

Based on the results of research data analysis through the twoway ANOVA test, it was obtained that the average learning outcome of students with high social skills was 84.36 while the average learning outcomes of students who had low social skills was 67.00 This proves that students social skills can affect student learning outcomes with the assumption that the higher the student's social skills, the higher the learning outcomes obtained by students.

Interaction between Discovery Learning Model and Learning Social Skills on Student Civics Learning Outcomes.

Discovery learning learning model is a learning model to understand concepts, meanings, and relationships through an intuitive 
process to finally arrive at a conclusion. In the discovery learning model, the teacher is tasked with guiding and directing students to be able to learn and think creatively. The trick is that the teacher only conveys the material in outline and then the students are required to find as much information as possible, compare, categorize, analyze, integrate and draw conclusions. The discovery learning model is applied in the learning process with the aim that students can better understand the material being studied by translating it into a language that is easier for them to understand.

Mussen, at al (Lismayanti, 2008) states that social skills are a term used by psychologists to refer to moral actions that are expressed culturally, such as sharing, helping someone in need, cooperating with others, and expressing sympathy. Citizenship Education has a good impact on student learning outcomes with the distribution of Citizenship Education learning outcomes of 20 people (83\%) in the group above the average. It is also written that self-regulation and social skills both have a positive relationship with Civics learning outcomes and to build student character at school, it is necessary for parents and teachers at school to play an active role with each other. Then if it is not taught with discovery learning,

The results of hypothesis testing using two-way ANOVA for the third hypothesis, namely the interaction between learning models and skills in influencing student learning outcomes, get a value of $=0.114$ and a significant value of 0.018 with $=0.05$. it can be seen that the significant value is $0.018<0.05$. then the hypothesis rejects $\mathrm{Ho}$ and accepts $\mathrm{Ha}$. Which means that there is an interaction between discovery learning learning models and social skills in influencing student Civics learning outcomes $F_{\text {count }} \propto$ 


\section{Conclusion}

Based on the formulation, objectives, results and discussion of the research on the effect of discovery learning and social skills learning models on PPKn learning outcomes for class V SDN 034799 DOLOKTOLONG previously stated, it can be concluded as follows:

a. There is an effect of student learning outcomes who are taught using the discovery learning learning model is higher than students who are taught using the expository learning model who get an average value of 85,556 , while the learning outcomes using the expository learning model get an average value of 76,944 , the results of the second analysis of variance the learning model shows the calculated $F$ of 71.11 which is greater than the value of $F$ table 3.20 at a significance level of 0.05 so that $H_{0}$ is rejected. Thus, it can be concluded that student learning outcomes using the discovery learning model are higher than the group of students who are taught using the expository learning model.

b. Based on the results of data calculations, it can be seen that the learning outcomes of students who are taught using discovery learning learning models and have high social skills get an average score of 84,364 while students who have low social skills get an average of 67.00 . The results of the analysis of variance of the two learning models show that the calculated $\mathrm{F}$ is 17.35 which is greater than the $F$ table value of 3.20 at the significance level 0.05 so that $\mathrm{H}_{0}$ is rejected. Thus it can be concluded that the group of students who have social skills obtain higher learning outcomes higher than the group of students with low social skills that is proven true.

c. There is an interaction between the learning model and students 
social skills in influencing learning outcomes. Students with high social skills will get higher results if they are taught with a discovery learning model and have high social skills. Likewise, students who have low social skills will get higher learning outcomes if they are taught using the discovery learning model. Based on the results of data calculations, it can be seen that the calculated $F$ is 4,021 greater than the $F$ table value of 3.20 at a significance level of 0.05 so that $H_{0}$ is rejected. Thus, it can be concluded that there is an interaction between learning models that have high social skills on student learning outcomes that are proven to be true.

\section{Bibliography}

Arikunto, S. 2003. Dasar-dasar Evaluasi Pendidikan. Jakarta: Bumi Aksara hasil-belajar/. Diunduh tanggal 11 Januari 2021 jam 19.15 WIB

Bahari, Ni Ketut Intan, dkk. 2018. Pengaruh Model Discovery Learning Berbantuan Media Lingkungan Alam Sekitar terhadap Hasil Belajar IPA. Jurnal Ilmiah Sekolah Dasar (Vol. 2, No. 2, 103-112).

Cand, Anak Agung Bagus Trisna Adi, dkk. 2017. Pengaruh Model Discovery Learning Terhadap Kompetensi Pengetahuan IPA Siswa Kelas VI SD Gugus Yos Sudarso Kecamatan Denpasar Selatan Tahun Pelajaran 2016/2017. Journal PGSD Universitas Pendidikan Ganesha (Vol. 5, No. 2, 2-10).

Cintia, Nichen Irma, dkk. 2018. Penerapan Model Pembelajaran Discovery Learning Untuk Meningkatkan Kemampuan Berpikir Kreatif dan Hasil Belajar Siswa. Jurnal Perspektif Ilmu Pendidikan (Vol.32, No.1, 69-77).

Hasnan, Syiti Mutia Hasnan, dkk. 2020. Pengaruh Penggunaan Model Discovery Learning dan Motivasi Terhadap Kemampuan Berpikir Kritis Peserta Didik Sekolah Dasar. Jurnal Basicedu (Vol. 4, No. 2, 239-249).

Michelson, Stuart E, James Wagner and Charles C Watta. (2000). The Relantionship between The Smoothing of Reported Income and 
Riskadjusted Returns, Journal of Economic and Finance, Summer: Vol 24 No 2: 141-159

Mussen, (1994). Perkembangan dan Kepribadian Anak. Jakarta: Arcan Noor.

Niswatuzzahro, Vivi, dkk. 2018. Penerapan Model Discovery Learning Berbantuan Media Audio Visual. Jurnal Pendidikan dan Kebudayaan (Vol. 8, No. 3, 273-284).

Ridwan.2008.

Ketercapaian

Prestasi

Belajar.

http://ridwan202.wordpress.com/200 8/05/03/ketercapaian-

prestasi-belajar/. Diunduh tanggal 25 juni 2021 jam14.35 WIB.

Samsul Hadi. Metodologi Penelitian. Jakarta. Raja Grafindo Persada. 2006. . Seri informasi Pendidikan Islam, No. 8, Manajemen Madrasah. Jakarta. Depag RI. 2001.

Shaffer, D. R. (2009). Social and Personality Development Sixth Edition. Belmont, California: Thomson Wadsworth.

Sumantri, Numan.(2001). Pembaharuan pendidikan IPS. Bandung: rosda Karya.

Suprijono, A. 2010. Cooperative Learning Teori dan Aplikasi Paikem. Yogyakarta: Pustaka Pelajar

Wardani, Fitria Intan Pramudi, dkk. 2018. Perbedaan Hasil Belajar

Matematika Kelas 4 SD dalam Pembelajaran Menggunakan Model Discovery Learning dan Problem Based Learning. Jurnal Teori dan Aplikasi Matematika (Vol. 2, No. 1, 62-75).

Winkel, WS. 1991. Psikologi Pendidikan dan Evaluasi Belajar. Jakarta: Gramedia. 